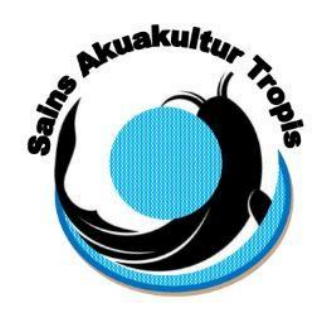

\section{EFEKTIVITAS PENAMBAHAN RAGI ROTI (Saccharomyces cerevisiae) PADA PAKAN BUATAN IKAN TAWES (Puntius javanicus) TERHADAP LAJU PERTUMBUHAN, EFISIENSI PEMANFAATAN PAKAN DAN KELULUSHIDUPAN}

The Effectiveness of Adding Bread Yeast (Saccharomyces cerevisiae) in Artificial Feed on Growth Rate, Food Utilization and Survival Rate of Java barb (Puntius javanicus)

Desy Sumardiyani, Diana Rachmawati*), Istiyanto Samidjan

Departemen Akuakultur

Fakultas Perikanan dan Ilmu Kelautan, Universitas Diponegoro

J1. Prof. Soedarto, SH, Tembalang, Semarang, Jawa Tengah -50275 , Telp/Fax. +6224 7474698

* Corresponding author: dianarachmawati1964@gmail.com

\begin{abstract}
ABSTRAK
Ikan tawes (Puntius javanicus) merupakan komoditas ikan air tawar yang bernilai ekonomis tinggi tetapi memiliki kendala didalam budidaya yaitu pertumbuhannya lambat dan pemanfaatan pakan yang kurang efisien. Salah satu solusi untuk mengatasi permasalahan tersebut adalah dengan penambahan ragi roti ( $S$. cerevisiae) pada pakan. Penelitian ini bertujuan untuk mengetahui pengaruh penambahan $S$. cerevisiae pada pakan terhadap tingkat kosumsi pakan (TKP), efisiensi pemanfaatan pakan (EPP), laju pertumbuhan spesifik (SGR) dan kelulushidupan. Materi yang digunakan adalah ragi roti (S. cerevisiae) yang dicampurkan pada pakan buatan ikan dengan cara disemprotkan dan setelah kering diberikan sebagai pakan ikan tawes. Penelitian dilakukan dengan metode ekperimental menggunakan rancangan acak lengap (RAL) dengan 4 perlakuan dan 3 kali pengulangan. Perlakuan yang diberikan yaitu dengan dosis A (0 g/kg pakan), B (3 g/kg pakan), C (6 g/kg pakan) dan D (9 g/kg pakan). Hewan uji yang digunakan adalah ikan tawes ( $P$. javanicus) sebanyak 120 ekor dengan bobot rata-rata $18,20 \pm 0,62$ g/ekor. Wadah yang digunakan pada penelitian adalah hapa dengan ukuran $50 \times 50 \times 50 \mathrm{~cm}^{3}$ dengan padat penebaran ikan tawes pada perlakuan yaitu 1 ekor/2 liter. Ikan tawes diberi makan 3 kali sehari sebanyak 5\% dari bobot biomassa. Hasil penelitian menunjukkan bahwa penambahan S. cerevisiae pada pakan memberikan pengaruh nyata $(\mathrm{P}<0,05)$ terhadap rasio konversi pakan $(\mathrm{FCR})$ dan pertumbuhan spesifik (SGR) tetapi tidak berpengaruh nyata $(\mathrm{P}>0,05)$ terhadap kelulushidupan. Hasil terbaik diperoleh pada pemberian pakan dengan dosis $3 \mathrm{~g} / \mathrm{kg}$ pakan (B) dengan nilai rasio konversi pakan (FCR) 1,28 $\pm 0,03$,

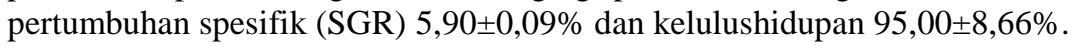

Kata Kunci : Saccharomyces cerevisiae, ikan tawes dan pertumbuhan

\title{
ABSTRACT
}

Fish tawes (Puntius javanicus) is a freshwater fish commodity of high economic value, but it has constraints in aquaculture that is slow growth and its utilization is less than efficient feed. One of the problem solve is utilization bread yeast (S. cerevisiae) in the artificial feed. The purpose of this study was to know and observe the effect of the addition of S. cerevisiae to feed on the level of feed consumption, feed utilization of, relative growth rate (RGR) and survival rate. The material used is bread yeast (S. cerevisiae) which is mixed with sprayed feed and after it is dried, then given as fish feed in culture. The experimental methods with completely randomized design (CRD) were employed in this research. The design consisted of 4 treatments and 
3 repepition. The treatments tested were A (0 g/kg feed), B (3 g/kg feed), C (6 g/ $\mathrm{kg}$ feed) and D (9 $\mathrm{g} / \mathrm{kg}$ feed).

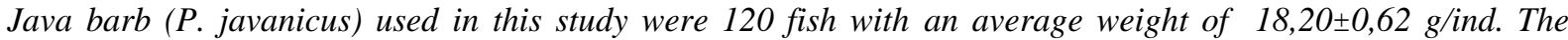
container used in this research was hapa with a size of $50 \times 50 \times 50 \mathrm{~cm}^{3}$, the initial density of fish were 1 ind/2 liter of water. Java barb (P. javanicus) were fed there times every day with $5 \%$ from biomass weight. The research results showed that the adding bread yeast ( $S$. cerevisiae) in the artificial feed were significantly effects $(P<0,05)$ on the food conversion ratio and specific growth rate $(S G R)$ but no significant effect $(P>0,05)$ on survival rate. The best result was in the treatment $B(3 \mathrm{~g} / \mathrm{kg}$ feed $)$ where the best food conversion ratio $(F C R)$

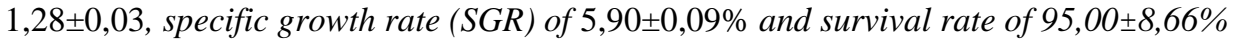

Key word : Saccharomyces cerevisiae, Puntius javanicus, growth

\section{PENDAHULUAN}

Ikan tawes merupakan jenis ikan air tawar asli Indonesia serta tergolong sebagai ikan pemakan tumbuhtumbuhan seperti alga, zooplankton dan tubuhan air seperti Hydrilla verticillata. Ikan tawes dapat dibudidayakan dengan baik dengan suhu air optimum antara 25-30 C (Laila, 2018). Ikan tawes memiliki keistimewaan yaitu bernilai ekonomi penting dan potensial untuk dibudidayakan karena tidak membutuhkan lahan yang terlalu istimewa serta ikan tawes merupakan ikan yang dapat dibudidayakan sepanjang tahun (Diana dan Eri, 2018). Namun terdapat kendala dalam kegiatan budidaya yaitu ikan tawes memiliki laju pertumbuhan yang lambat hal ini diduga karena pakan yang diberikan belum efisien. Salah satu solusi untuk mengatasi permasalahan laju pertumbuhan pada ikan tawes yaitu dengan penambahan suplemen ragi roti (Saccharomyces cerevisiae) pada pakan komersil. Penambahan ragi roti per kg pakan dapat meningkatkan performa pertumbuhan dan pengambilan pakan. Hal ini diperkuat oleh Manurung dan Numisye (2018), ragi roti dapat meningkatkan nafsu makan ikan sehingga pengambilan pakan meningkat. Hal ini membuat ikan cenderung makan dan mampu mencerna pakan dengan baik sehigga pertumbuhan meningkat.

Penambahan ragi roti (S. cerevisiae) sudah dilakukan pada beberapa jenis ikan air tawar maupun air laut. Ragi roti (S. cerevisiae) berpengaruh terhadap laju pertumbuhan ikan karena terdapat nukleotida dalam ragi roti dimana nukleotida dapat meningkatkan nafsu makan ikan sehingga pengambilan pakan meningkat dan pertumbuhan meningkat. Hal ini diperkuat oleh Rawung dan Henky (2014), nukleotida adalah nutriet semi esensial dan bahan ini dibutuhkan untuk pertumbuhan dan perbanyakan sel organisme hidup serta mengoptimalkan fungsi-fungsi pembelahan sel termasuk sel-sel imun. Nukleotida akan diurai oleh enzim nukleotridase untuk melepas molekul fosfat dan menghasilkan nukleosida. Nukleosida kemudian diurai oleh enzim nukleosidase untuk melepas molekul gula dan menghasilkan basa purin dan pirimidin. Purin dan pirimidin akan digunakan untuk membentuk nukleotida yang dibutuhkan untuk pembentukan DNA dan perbanyakan atau pembentukan sel baru.

Penelitian tentang penambahan ragi roti (S. cerevisiae) pada beberapa spesies ikan antara lain: ikan kerapu (Bugis dan Henky, 2014); Oreochromis niloticus (Rahman et al., 2017); Cyprinus carpio (Al-Refaiee et al., 2016); dan Pangasius hypothalamus (Rachmawati et al., 2019). Menurut Bugis dan Henky (2014), ragi roti merupakan bahan yang mengandung nukleotida yang tinggi sehingga dapat digunakan sebagai pengganti nukleotida murni. Nukleotida yang diekstrak dari ragi roti dan ditambahkan dalam pakan ikan nila dapat meningkatkan pertumbuhan ikan nila. Oleh karena itu, studi mengenai penambahan ragi roti (S. cerevisiae) pada ikan tawes perlu dilakukan. Penambahan ragi roti dalam pakan diduga dapat meningkatkan pertumbuhan.

Penelitian ini bertujuan untuk mengetahui pengaruh, dosis terbaik dan dosis optimal penambahan $S$. cerevisiae pada pakan buatan terhadap rasio konversi pakan (FCR), pertumbuhan spesifik (SGR) dan kelulushidupan ikan tawes (P. javanicus). Penelitian ini dilakukan pada bulan Februari-April 2019 di Laboratorium Pengujian Kesehatan Ikan dan Lingkungan (LPKIL) Magelang, Jawa Tengah.

\section{MATERI DAN METODE}

Ikan uji yang digunakan dalam penelitian ini adalah ikan tawes ( $P$. javanicus) dengan bobot rata-rata 18,20 $\pm 0,62$ g/ekor. Ikan uji berasal dari Laboratorium Pengujian Kesehatan Ikan dan Lingkungan (LPKIL) Magelang, Jawa Tengah. Wadah yang digunakan dalam penelitian ini adalah hapa hitam dengan ukuran 50x50x50 $\mathrm{cm}^{3}$ sebanyak 12 hapa yang diletakkan pada kolam. Media pemeliharaan pada penelitian ini menggunakan air tawar yang berasal dari sungai yang dialirkan ke dalam kolam pemeliharaan. Ikan dilakukan pemuasaan selama satu hari sebelum dilakukan perlakuan yang bertujuan untuk membuang sisa metabolisme dari pakan yang telah diberikan sebelumnya.

Rancangan percobaan yang digunakan adalah Rancangan Acak Lengkap (RAL) dengan 4 perlakuan 3 pengulangan dengan perlakuan penambahan suplemen Saccharomyces cerevisiae sebagai berikut: 
Perlakuan A : $0 \mathrm{~g} / \mathrm{kg}$ pakan

Perlakuan B : $3 \mathrm{~g} / \mathrm{kg}$ pakan

Perlakuan $\mathrm{C} \quad: 6 \mathrm{~g} / \mathrm{kg}$ pakan

Perlakuan D : $9 \mathrm{~g} / \mathrm{kg}$ pakan

Rancangan penelitian dengan dosis $0 \mathrm{~g}, 3 \mathrm{~g}, 6 \mathrm{~g}$, dan $9 \mathrm{~g}$ penambahan Saccharomyces cerevisiae pada pakan buatan ikan tawes merupakan modifikasi penelitian Razak et al. (2017), dengan hasil pertumbuhan mutlak terbaik dicapai pada perlakuan B (5 g/kg pakan) dalam waktu penelitian 3 minggu. Persiapan pakan yang digunakan yaitu ragi roti ditimbang sesuai dengan dosis yang dibutuhkan kemudian ragi roti yang telah ditimbang disuspensikan dalam akuades, untuk pembuatan $1 \mathrm{~kg}$ pakan jumlah akuades yang dibutuhkan adalah $100 \mathrm{~mL}$. Suspensi ragi roti dimasukkan dalam sprayer kemudian disemprotkan secara merata pada pakan. Pakan yang telah disemprotkan ragi roti dikering anginkan dalam suhu ruang. Pakan uji diberikan tiga kali dalam sehari yaitu pukul 08:0 WIB, 12:00 WIB dan 16:00 WIB. Setelah kering pakan dimasukkan dalam wadah dan disimpan dalam lemari pendingin sampai saat digunakan. Proksimat pakan yang diberi S. cerevisiae tersaji pada tabel 1 .

Tabel 1. Proksimat Pakan Perlakuan Penambahan Ragi Roti (S. cerevisiae)

\begin{tabular}{ccccc}
\hline \multirow{2}{*}{ Perlakuan } & \multicolumn{4}{c}{ Hasil Analisa (\%) } \\
\cline { 2 - 5 } & Protein & Lemak & $\begin{array}{c}\text { Serat } \\
\text { Kasar }\end{array}$ & Abu \\
\hline A $(0 \mathrm{~g} / \mathrm{kg})$ & 30,57 & 3,76 & 6,31 & 10,54 \\
B (3 g/kg) & 30,76 & 3,73 & 9,36 & 9,13 \\
C (6 g/kg) & 31,01 & 3,69 & 9,78 & 9,40 \\
D (9 g/kg) & 30,74 & 6,97 & 11,11 & 9,50 \\
\hline
\end{tabular}

Sumber: Laboratotium Ilmu Nutrisi dan Pakan, Fakultas Peternakan dan Pertanian Universitas Diponegoro, Semarang (2019)

Variabel Pengamatan

\section{a. Rasio Konversi Pakan (FCR)}

Rasio Konversi Pakan (FCR) dapat dihitung dengan menggunakan rumus berdasarkan Santoso dan Agusmansyah (2012), yaitu sebagai berikut:

$$
\mathrm{FCR}=\frac{\mathrm{F}}{\mathrm{Wt}-\mathrm{W} 0} \times 100 \%
$$

keterangan:

FCR : Rasio Konversi Pakan

F : jumlah pakan yang diberikan $(\mathrm{g})$

$\mathrm{W}_{\mathrm{t}}$ : bobot rata-rata ikan pada akhir pemeliharaan $(\mathrm{g})$

$\mathrm{W}_{0} \quad$ : bobot rata-rata ikan pada awal pemeliharaan $(\mathrm{g})$

\section{b. Pertumbuhan Spesifik (SGR)}

Laju pertumbuhan spesifik harian (SGR) ikan dihitung dengan menggunakan rumus dari Effendi (1997) berikut ini:

keterangan:

$$
\mathrm{SGR}=\frac{\ln \mathrm{Wt}-\ln \mathrm{Wo}}{\mathrm{t}} \times 100 \%
$$

SGR : pertumbuhan spesifik harian ( $\%$ per hari)

Wo : bobot rata-rata ikan pada awal pemeliharaan $(\mathrm{g})$

$\mathrm{Wt}$ : bobot rata-rata ikan pada akhir pemeliharaan $(\mathrm{g})$

t : waktu pemeliharaan (hari)

\section{c. Kelulushidupan}

Menurut Effendi (1997), Survival Rate (SR) merupakan prosentase kelulushidupan ikan yang dapat dihitung dengan rumus sebagai berikut:

$$
\mathrm{SR}=\frac{\mathrm{No}}{\mathrm{Nt}} \times 100 \%
$$


Keterangan :

$\mathrm{SR} \quad=$ Tingkat kelulushidupan ikan (\%)

$\mathrm{N}_{\mathrm{t}} \quad=$ Jumlah ikan uji pada akhir penelitian (ekor)

$\mathrm{N}_{0} \quad=$ Jumlah ikan uji pada awal penelitian (ekor)

\section{d. Kualitas Air}

Pengamatan kualitas air meliputi suhu, tingkat keasaman (pH), oksigen terlarut (DO) dan kandungan ammonia $\left(\mathrm{NH}_{3}\right)$. Pengamatan kualitas air yang terdiri dari kandungan ammonia $\left(\mathrm{NH}_{3}\right)$ dilakukan pada awal, tengah dan akhir penelitian, sedangkan pengamatan kualitas air seperti suhu, $\mathrm{pH}$ dan DO dilakukan setiap hari.

\section{HASIL DAN PEMBAHASAN}

\section{Hasil}

Hasil analisis ragam menunjukkan bahwa penambahan ragi roti (S. cerevisiae) pada pakan memberikan pengaruh nyata $(\mathrm{P}<0,05)$ terhadap efisiensi pemanfaatan pakan $(\mathrm{EPP})$ dan laju pertumbuhan $(\mathrm{RGR})$ ikan tawes ( $P$. javanicus). Namun, penambahan ragi roti (S. cerevisiae) pada pakan tidak memberikan pengaruh nyata $(\mathrm{P}>0,05)$ terhadap tingkat konsumsi pakan (TKP) dan kelulushidupan ikan tawes $(P$. javanicus $)$. Hasil ditandai dengan huruf superscript yang berbeda disetiap variabel, menunjukkan berbeda nyata $(P>0,05)$ sedangkan huruf superscript yang sama, menunjukkan tidak berbeda nyata $(\mathrm{P}<0,05)$. Hasil TKP, EPP, RGR dan kelulushidupan ikan tawes ( $P$. javanicus) selama penelitian tersaji pada Tabel 2.

Tabel 2. Hasil Nilai TKP, EPP, RGR dan Kelulushidupan Ikan Tawes (P. javanicus) Selama Penelitian

\begin{tabular}{lrrrr}
\hline \multirow{2}{*}{ Parameter } & \multicolumn{4}{c}{ Perlakuan } \\
\cline { 2 - 5 } & \multicolumn{1}{c}{$\mathrm{A}$} & $\mathrm{B}$ & $\mathrm{C}$ & $\mathrm{D}$ \\
\hline FCR & $2,12 \pm 0,40^{\mathrm{b}}$ & $1,28 \pm 0,03^{\mathrm{a}}$ & $1,55 \pm 0,18^{\mathrm{ab}}$ & $1,89 \pm 0,21^{\mathrm{b}}$ \\
SGR (\%/hari) & $5,60 \pm 0,05^{\mathrm{c}}$ & $5,90 \pm 0,09^{\mathrm{a}}$ & $5,79 \pm 0,01^{\mathrm{b}}$ & $5,67 \pm 0,02^{\mathrm{c}}$ \\
Kelulushidupan (\%) & $91,67 \pm 2,89^{\mathrm{a}}$ & $95,00 \pm 8,66^{\mathrm{a}}$ & $93,33 \pm 5,77^{\mathrm{a}}$ & $88,33 \pm 2,89^{\mathrm{a}}$ \\
\hline
\end{tabular}

Keterangan: huruf superscript yang sama menunjukkan tidak terdapat perbedaan yang nyata $(\mathrm{P}>0,05)$

Hubungan variabel respon biologis dan persamaan regresi ikan tawes ( $P$. javanicus) yang diberi pakan dengan tambahan $S$. cerevisiae terhadap EPP dan RGR berdasarkan uji polinomial orthogonal tersaji pada Gambar 1 dan 2.

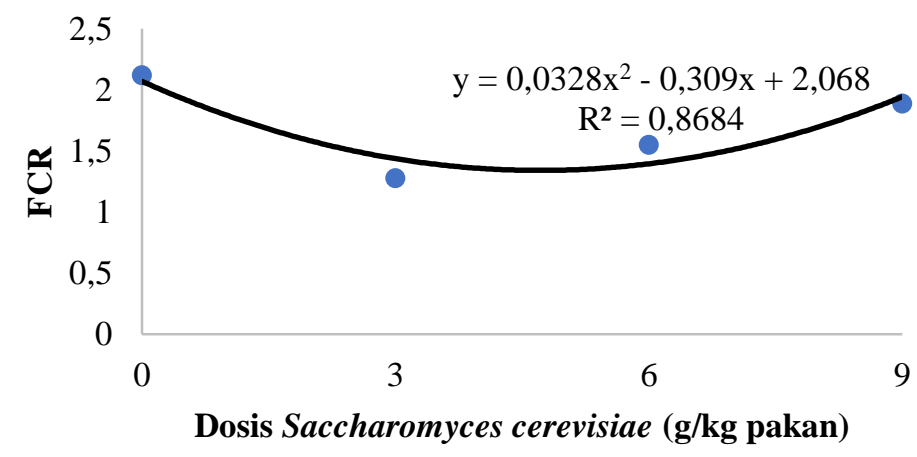

Gambar 1. Grafik Polinomial Orthogonal Rasio Konversi Pakan (FCR) Ikan Tawes (P. javanicus) Selama Penelitian 


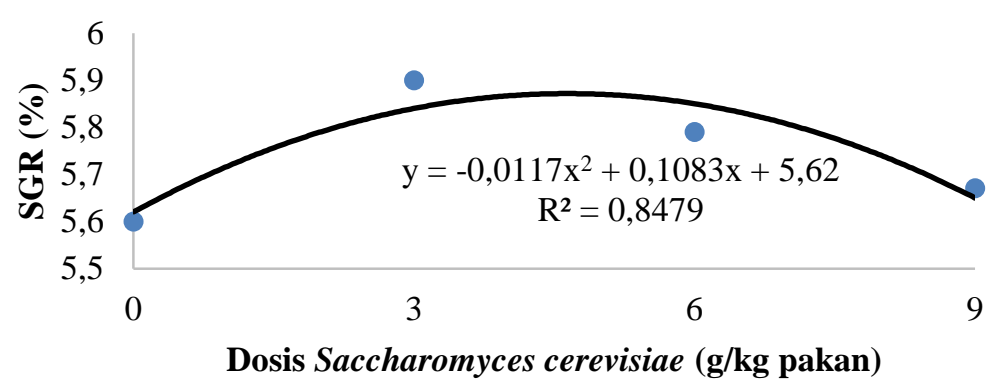

Gambar 2. Grafik Polinomial Orthogonal SGR (\%/Hari) Ikan Tawes (P. javanicus) Selama Penelitian

\section{Kualitas air}

Nilai parameter kualitas air sebagai data pendukung dalam penelitian meliputi DO, pH, suhu dan ammonia yang tersaji pada Tabel 3 .

Tabel 3. Hasil Nilai Kualitas Air Pada Ikan Tawes (P. javanicus) Selama Penelitian

\begin{tabular}{lccccc}
\hline \multirow{2}{*}{ Parameter } & \multicolumn{3}{c}{ Perlakuan } & \multicolumn{2}{c}{ Kisaran Nilai } \\
Pustaka
\end{tabular}

Hasil pengukuran kualitas air menunjukkan bahwa nilai kualitas air selama penelitian masih dalam kisaran yang layak untuk dijadikan media budidaya ikan tawes ( $P$. javanicus), hal ini didasarkan dari pustaka tentang kondisi kualitas air yang optimum untuk ikan tawes (P. javanicus).

\section{Pembahasan}

a. Rasio Konversi Pakan (FCR)

Penambahan ragi roti dalam pakan buatan dengan dosis masing-masing ( $0 \mathrm{~g}, 3 \mathrm{~g}, 6 \mathrm{~g}$ dan $9 \mathrm{~g})$ memberikan pengaruh nyata $(\mathrm{P}<0,05)$ terhadap rasio konversi pakan $(\mathrm{FCR})$. Hal ini diduga karena ragi roti mengandung mannaoligosaccharidae yang dapat meningkatkan rasio konversi pakan. Menurut Abu-Elala et al., (2013), ekstrak dinding sel ragi roti ( $S$. cerevisiae) adalah immunostimulan alami yang berperan sebagai penggerak pertumbuhan sehingga dapat meningkatkan pertambahan berat badan dan rasio konversi pakan.

Nilai rasio konversi pakan dengan penambahan ragi roti dalam pakan buatan menunjukkan nilai rata-rata tertinggi pada perlakuan A sebesar 2,12 $\pm 0,40$ dan terendah pada perlakuan B sebesar 1,28 $\pm 0,03$. Nilai konversi pakan terbaik pada perlakuan B (3 g/kg pakan) sebesar 1,28. Nilai konversi pakan yang baik pada perlakuan B juga didukung oleh nilai EPP terbaik pada perlakuan B 74,84\%. Rendahnya nilai FCR dan meningkatnya nilai EPP menunjukkan bahwa pakan yang diberikan termanfaatkan dengan baik untuk pertumbuhan ikan. Besar kecilnya rasio konversi pakan (FCR) menentukan efektivitas pakan tersebut. Nilai rasio konversi pakan (FCR) berbanding terbalik dengan efisiensi pemanfaatan pakan. Hal ini diperkuat oleh Setiawati (2013), nilai efisiensi pakan berbanding terbalik dengan konversi pakan dan berbanding lurus dengan pertambahan berat tubuh ikan, sehingga semakin tinggi nilai efisiensi pemanfaatan pakan maka nilai konversi pakan semakin rendah dan ikan semakin efisien memanfaatkan pakan yang dikonsumsi untuk pertumbuhan. Nilai konversi pakan dipengaruhi oleh jumlah pakan yang diberikan, semakin sedikit pakan yang diberikan maka pemberian pakan semakin efisien.

\section{b. Pertumbuhan Spesifik (SGR)}

Pertumbuhan spesifik (SGR) ikan tawes yang diberi perlakuan penambahan S. cerevisiae pada pakan 
dengan dosis masing-masing $(0 \mathrm{~g}, 3 \mathrm{~g}, 6 \mathrm{~g}$ dan $9 \mathrm{~g})$ memberikan pengaruh nyata $(\mathrm{P}<0,05)$ terhadap laju pertumbuhan spesifik (SGR). Hal ini diduga ragi roti mengandung nukleotida sehingga penambahan ragi roti dalam pakan buatan memberi pengaruh nyata terhadap laju pertumbuhan spesifik Hal ini diperkuat oleh Manoppo dan Magdalena (2015), penambahan ragi roti dapat meningkatkan pertumbuhan karena ragi roti mengandung nukleotida dalam bentuk basah purin dan pirimidin sebanyak $0,9 \%$. Peningkatan pertumbuhan melalui penambahan ragi roti dalam pakan terjadi karena nukleotida yang terkandung dalam ragi roti dapat meningkatkan nafsu makan ikan sehingga pengambilan pakan meningkat.

Perlakuan terbaik penambahan S. cerevisiae terhadap SGR ikan tawes menunjukkan nilai terbaik pada perlakuan B 5,90\% dan nilai SGR terendah pada perlakuan A 5,60. Hal ini menunjukkan bahwa penambahan ragi roti pada pakan dapat meningkatkan pertumbuhan ikan hal ini dibuktikan dengan perbandingan nilai SGR pada penelitian yang tertinggi didapatkan pada perlakuan B dengan dosis penambahan ragi roti $3 \mathrm{~g} / \mathrm{kg}$ pakan. Namun penambahan ragi roti pada pakan yang berlebih juga tidak baik untuk pertumbuhan ikan. S. cerevisiae menghasilkan metabolit yang berbeda sehingga meningkatkan sekresi enzim lambung, meningkatkan pencernaan makanan dan kinerja pertumbuhan. Menurut Mohammadi et al. (2016), ragi roti dapat melekat pada usus saat proses pencernaan hal ini menyebabkan peningkatan sekresi amilase dan meningkatkan aktivitas enzim pencernaan sehingga dapat meningkatkan kecernaan nutrisi. Penambahan ragi roti dapat meningkatkan pola makan sehingga menunjukkan pertumbuhan dan efisiensi pakan yang lebih baik. Menurut Nurkhotimah (2017), faktor yang mempengaruhi aktivitas enzim adalah konsentrasi enzim, suhu, $\mathrm{pH}$ substrat, inhibitor dan aktivator. Hal ini dikarenakan setiap enzim memiliki $\mathrm{pH}$ dan suhu optimum, jika suhu dibawah suhu optimum maka aktivitas enzim akan rendah, demikian juga dengan $\mathrm{pH}$, jika dilakukan proses di bawah $\mathrm{pH}$ optimum maka aktivitas enzim rendah. Hal ini terjadi karena struktur tiga dimensi enzim mulai berubah sehingga substrat tidak dapat berikatan dengan sisi aktif enzim akibatnya proses katalis tidak dapat berlangsung secara sempurna.

Menurut Huyben et al. (2017), ragi roti merupakan protein sel tunggal yang bagus digunakan sebagai pakan ikan. S. cerevisiae mengandung protein kasar dan profil asam amino yang mirip dengan tepung ikan. Hasil penelitian ini serupa dengan hasil penelitian yang dilaporkan oleh Manoppo dan Magdanela (2015), laju pertumbuhan ikan nila dengan penambahan ragi roti pada pakan sebesar $10 \mathrm{~g} / \mathrm{kg}$ pakan menunjukkan hasil yang lebih besar yaitu $15 \%$ /hari dan terendah pada pakan tanpa tambahan ragi roti (0 g/kg pakan) sebesar 8,33 $\% /$ hari.

\section{c. Kelulushidupan}

Penambahan ragi roti dalam pakan buatan dengan dosis masing-masing $(0 \mathrm{~g}, 3 \mathrm{~g}, 6 \mathrm{~g}$ dan $9 \mathrm{~g})$ tidak memberikan pengaruh nyata $(\mathrm{P}>0,05)$ terhadap kelulushidupan. Hal ini diduga karena faktor lingkungan yang baik menyebabkan nilai kelulushidupan ikan baik. Hasil penelitian menunjukkan kisaran nilai kelulushidupan pada ikan tawes (P. javanicus) yaitu 93,33\%-100\%. Nilai kelulushidupan yang didapatkan dari hasil penelitian menunjukkan nilai kelulushidupan yang baik karena jumlah kematian ikan hanya sedikit. Dosis ragi roti sebesar $3 \mathrm{~g} / \mathrm{kg}$ pakan, $6 \mathrm{~g} / \mathrm{kg}$ pakan dan $9 \mathrm{~g} / \mathrm{kg}$ pakan tidak menimbulkan masalah yang dapat menyebabkan kematian ikan sehingga dosis tersebut termasuk dalam batas yang aman untuk dicampurkan pada pakan. Menurut Subandiyono et al. (2018), nilai kelulushidupan ikan pada percobaan dipengaruhi oleh kualitas air terutama $\mathrm{pH}$. Kesamaan nilai kelulushidupan menunjukkan bahwa parameter kualitas air sepanjang periode percobaan sesuai denga $P$. javanicus dan berada dalam batas yang diinginkan dari ikan.

Kelulushidupan merupakan perbandingan antara jumlah ikan yang hidup pada akhir pemeliharaan dengan jumlah ikan yang hidup pada awal pemeliharaan. Kelulushidupan dapat digunakan sebagai tolak ukur untuk mengetahui toleransi dan kemampuan ikan untuk hidup. Hal yang mempengaruhi nilai kelulushidupan yaitu pemberian pakan yang baik sehingga dapat mendukung pertumbuhan ikan dan ikan dapat mempertahankan hidupnya melalui energi yang didapatkan dari pakan. Kelulushidupan dipengaruhi oleh faktor abiotik seperti kemampuan menyesuaikan diri dengan lingkungan, penanganan manusia, jumlah populasi, kompetitor, penyakit, umur serta ada atau tidaknya predator. Hal ini juga diperkuat oleh Hanief et al. (2014), faktor yang mempengaruhi tinggi rendahnya kelangsungan hidup adalah abiotik dan biotik antara lain kompetitor, kepadatan, populasi, umur dan kemampuan organisme beradaptasi dengan lingkungannya.

\section{KESIMPULAN DAN SARAN \\ Kesimpulan}

Kesimpulan dari hasil penelitian adalah sebagai berikut:

1. Penambahan ragi roti $(S$. cerevisiae) pada pakan memberikan pengaruh nyata $(\mathrm{P}<0,05)$ terhadap rasio konversi pakan (FCR) dan pertumbuhan spesifik (SGR) ikan tawes (P. javanicus). Namun penambahan 
ragi roti $(S$. cerevisiae) pada pakan tidak memberikan pengaruh nyata $(\mathrm{P}>0,05)$ terhadap kelulushidupan ikan tawes ( $P$. javanicus);

2. Dosis terbaik untuk penambahan ragi roti (S. cerevisiae) pada pakan ikan tawes (P. javanicus) terdapat pada perlakuan B dengan dosis $3 \mathrm{~g} / \mathrm{kg}$ pakan; dan

3. Dosis optimum untuk penambahan ragi roti ( $S$. cerevisiae) pada pakan terhadap FCR dan RGR yaitu masing-masing pada kisaran 4,83 g/kg pakan dan 4,62 $\mathrm{g} / \mathrm{kg}$ pakan.

\section{SARAN}

Saran dari hasil penelitian ini adalah penambahan ragi roti (S. cerevisiae) pada pakan pada dosis optimal antara 4,35-4,83 $\mathrm{g} / \mathrm{kg}$ pakan dapat diterapkan pada budidaya ikan tawes.

\section{UCAPAN TERIMAKASIH}

Terima kasih kepada LPKIL (Laboratorium Pengujian Kesehatan Ikan dan Lingkungan) Muntilan, Magelang yang telah menyediakan tempat penelitian.

\section{DAFTAR PUSTAKA}

Abu-Elala, N., M. Marzouk and M. Moustafa. 2013. Use of Different Saccharomyces cerevisiae Biotic Forms as Immune-modulator and Growth Promoter For Oreochromis niloticus Challenged With Some Fish Pathogens. International Journal of Veterinary Science and Medicine. 1: 21-29.

Al-Refaiee, I. H., N. M. Abdulrahman and H. A. Mutter. 2016. Replacement of Commercial Dry Yeast (Saccharomyces cerevisiae) with Animal Protein Concentrate and Its Effect in Some Blood Parameters for Fingerlings Common Carp Cyprinus Carpio L. Basrah Journal of Veteriner Research. 15(3): 312332.

Bugis, A. A. dan H. Manoppo. 2014. Peningkatan Pertumbuhan Ikan Nila (Oreochromis niloticus) Melalui Pemberian Immunostimulan Ragi Roti (Saccharomyces cerevisiae). Budidaya Perairan. 2(3): 1-7.

Boyd, C. T. 1979. Water Quality in Warmwater Fish Pond. Auburn University Press, Alabama, 359 p.

Diana, F dan E. Safutra. 2018. Pengaruh Pemberian Pakan Alami yang Berbeda pada Benih Ikan Tawes (Barbonymus gonionotus) terhadap Pertumbuhan dan Kelangsungan Hidup. Jurnal Akuakultura. 2(1): 19.

Effendi, M. I. 1997. Metode Biologi Perikanan. Gramedia Pustaka Utama. Jakarta. 69 hlm.

Hanief, M. A., Subandiyono dan Pinandoyo. 2014. Pengaruh Frekuensi Pemberian Pakan Terhadap Pertumbuhan dan Kelulushidupan Benih Tawes (Puntius javanicus). Journal of Aquaculture Management and Technology. 3(4): 67-74.

Huyben, D., A. Nyman, A. Vidakovic, V. Passoth, R. Moccia, A. Kiesling, J. Dicksved and T. Lundh. 2017. Effects of Dietary Inclusion of The Yeast Saccharomyces cerevisiae and Wickerhamomyces Anomalus on Gut Microbiota of Rainbow trout. Aquaculture. 473: 528-537.

Laila, K. 2018. Pertumbuhan Ikan Tawes (Puntius javanicus) di Sungai Linggahara Kabupaten Labuhanbatu, Sumatera Utara. Jurnal Pionir LPPM Universitas Asahan. 2(4): 1-5.

Manoppo, H dan M. E. F. Kolopita. 2015. Pengimbuhan Ragi Roti dalam Pakan Meningkatkan Respons Imun Nonspesifik dan Pertumbuhan Ikan Nila. Jurnal Veteriner. 16(2): 204-211.

Manurung, U. N dan M. I. Mose. 2018. Peningkatan Pertumbuhan dan Sintasan Hidup Ikan Bawal (Colossoma macropumum) dengan Penambahan Ragi Roti dalam Pakan. Jurnal Saintek Lahan Kering. 2: 26-27.

Mohammadi, F., S. M. Mousavi, M. Zakeri and E. Ahmadmoradi. 2016. Effect of Dietary Probiotic, Saccharomyces cerevisiae on Growth Performance, Survival Rate and Body Biochemical Composition of Three Spot Cichlid (Cichlasoma trimaculatum). AACL Bioflux. 9(3): 451-457.

Moniruzzaman, Mohammad., K. B. Uddin., S. Basak dan A. Bashar. 2015. Effects of Stocking Density on Growth Performance and Yield of Thai Silver Barb Barbonymus gonionotus Reared in Floating Net Cages in Kaptai Lake, Bangladesh. AACL BIOFLUX., 8(6): 999 - 108.

Nurkhotimah. 2017. Pengaruh Suhu dan pH Terhadap Aktivitas Enzim Fosfatae Bakteri Termofilik Sungai Gendol Pasca Erupsi Merapi. Jurnal Prodi Biologi. 6(8): 465-471.

Rachmawati, D., I. Samidjan, R. A. Nugroho and T. Susilowati. 2019. Effects of Saccharomyces cerevisiae Incorporated Diet on Growth Performance, Apparent Digestibility Coefficient of Protein and Survivall Rate of Catfish (Pangasius hypothalamus). Aquacultura Indonesiana. 20(1): 8-14. 
Rahman, A. N., S. A. Abdellatief and H. H. H. Mahboub. 2017. Protection of Nile Tilapia, Oreochromis niloticus from Aflatoxin $B_{1}$ Toxicity by Dietary Supplementation with Fennel Essential Oil and Saccharomyces cerevisiae. Egyptian Journal of Aquatic Research. 43: 235-240.

Razak, A. P., R. L. Kreckhoff dan J. C. Watung. 2017. Administrasi Oral Imunostimulan Ragi Roti (Saccharomyces cerevisiae) untuk Meningkatkan Pertumbuhan Ikan Mas (Cyprinus Carpio L.). Budidaya Perairan. 5(2): 27-36.

Rawung, M. E dan H.. Manoppo. 2014. Penggunaan Ragi Roti (Saccharomyces cerevisiae) secara In Situ unutk Meningkatkan Respon Kebal Non-spesifik Ikan Nila (Oreochromis niloticus). Budidaya Perairan. 2(2): 7 14.

Santoso L., Agusmansyah H. 2012. Pengaruh Substitusi Tepung Kedelai dengan Tepung Biji Karet pada Pakan Buatan terhadap Pertumbuhan Ikan Bawal Air Tawar (Colossoma macropomum). Berkala Perikanan Terubuk. 39(2): 41-50.

Setiawati, J. E., Tarsim, Y. T. Adiputra dan S. Hudaidah. 2013. Pengaruh Penambahan Probiotik pada Pakan dengan Dosis Berbeda Terhadap Pertumbuhan, Kelulushidupan, Efisiensi Pakan dan Retensi Protein Ikan Patin (Pangasius hypophthalmus). E-Jurnal Rekayasa dan Teknologi Budidaya Perairan. 1(2): 151-162.

Subandiyono, S. Hastuti dan R. A. Nugroho. 2018. Feed Utilization Efficiency amd Growth of Java barb (Puntius javanicus) Fed on Dietary Pineapple Extract. AACL Bioflux. 11(2): 309-318.

Zonnevald, N., Huisman. E.A dan Boon. J.H. 1991. Prinsip-Prinsip Budidaya Ikan. Gramedia Pustaka Utama, Jakarta, 318 hlm. 